\title{
Religious Difference in a Secular Age: The Minority Report by Saba Mahmoud (2016) Book Review
}

Lama Abu-Odeh

Georgetown University Law Center, la34@law.georgetown.edu

This paper can be downloaded free of charge from:

https://scholarship.law.georgetown.edu/facpub/1951

https://ssrn.com/abstract=2927118

Lama Abu-Odeh, Secularism's Fault, Feminist Dissent, Summer 2017, at 148-161 (reviewing Saba Mahmood, Religious Difference in a Secular Age: A Minority Report (2016)).

This open-access article is brought to you by the Georgetown Law Library. Posted with permission of the author. Follow this and additional works at: https://scholarship.law.georgetown.edu/facpub

Part of the Religion Law Commons 


\author{
Book Review of \\ Saba Mahmood's Religious Difference in a Secular Age: The Minority Report, \\ Princeton University Press (2016)
}

Lama Abu Odeh

Saba Mahmood is not a huge fan of political secularism, particularly, in its modern liberal expression as the twin principles of religious liberty $(R L)$ and (religious) minority rights (MR). In her book, Religious Difference in a Secular Age: A Minority Report, that uses the beleaguered plight of the Egyptian Copts to think of secularism "critically", Mahmood contends that the culprit for their state of siege, suffering discrimination as individuals and periodic sectarian assault from religious majority Muslims as community, is not so much the incomplete secularism of Egypt, Egypt's religiosity as one might be tempted to think, rather its Egypt's political secularism per se. This is so because secularism's promise of freedom of religion/minority rights granted to the Copts of Egypt, as expressed in the formal liberal legal system of Egypt, fails to deliver on their promise of protection because of the nature of state intervention they invite. For the sad fact is that secularism's promise quickly turns into its threat. The liberal legal principle of "religious liberty" ends up giving license to the state to define and regulate the very religion it claims to grant a "laissez faire" to and its promise of minority rights only adds to the predicament of this minority by defining it as such. The minority status makes them "stick out like a sore thumb" so to speak exposing them to further attack and causing them to recoil in unhealthy ways in their particularity, attached to their church and their religious doctrine, and driving them into damaging alliances with authoritarian dictatorships for protection. This is not the lone fate of the religious minority of Egypt, Mahmood argues, but of that of any country that adopts the legal liberal expressions of secularism that Egypt does, even those like Western democracies historically steeped in secularist traditions. What difference in status Western religious minorities have from the Copts of Egypt can only be attributed to the difference in interpretation religious majorities of the respective countries end up giving to the twin legal expressions of secularism (RL and $M R$ ). The 
menace of secularism on these religious minorities might differ but it is there wherever secularism treads its liberal path ${ }^{1}$.

But if not secularism with its twin liberal principles then what? It is not entirely clear. Mahmood's critical discourse sometimes waxes anarchist, at times libertarian and at many others, traditionalist conservative (nostalgic for the pre-modern). For instance, she offers by way of nostalgic references to the premodern times of the Ottoman empire a possible alternative to the contemporary globalized ideal of political secularism, riding roughshod on the back of the overbearing modern state, when Ottoman religious (non-Muslim) communities enjoyed an independent corporate status as Ahl Al Zimma in exchange for accepting their formal inequality to the Muslim majority of the self-avowedly Muslim Caliphate. The idea being that the pre- modern state is not as heavily interventionist as the modern one choosing instead to run its various communities through six degrees of separation that had allowed such communities independence in defining their internal doctrines and in running their communal affairs. If they had to pay Jizya (tax) to buy off their corporate independence and if they had to be formally placed as second in status to the Muslim majority then the trade-off may not have been so bad. In other words, Mahmood seems to suggest that the trade-off between secondclass status for corporate status is superior to the one posited by the modern secular state between equal citizenship for minoritarian status combined with the grant of religious liberty.

\footnotetext{
${ }^{1}$ Mahmood says, "While Islamic concepts and practices are crucial to the production of this inequality, I argue that the modern state and its political rationality have played a far more decisive role in transforming preexisting religious differences, producing new forms of communal polarization, and making religion more rather than less salient to minority and majority identities alike. Furthermore, I suggest that insomuch as secularism is characterized by a globally shared form of national-political structuration, the regulation of religious difference takes a modular form across geographical boundaries. Two paradoxical features of this secular political rationality are particularly germane. First, its claim to religious neutrality notwithstanding, the modern state has become involved in the regulation and management of religious life to an unprecedented degree, thereby embroiling the state in substantive issues of religious doctrine and practice. Second, despite the commitment to leveling religious differences in the political sphere, modern secular governance transforms - and in some respects intensifiespreexisting interfaith inequalities, allowing them to flourish in society, and hence for religion to striate national identity and public norms. While these features characterize all modern states, in the case of non-Western polities such as Egypt they are often judged to be the signs of their incomplete secularization.
}

Mahmood, Saba (2015-11-03). Religious Difference in a Secular Age: A Minority Report (p. 2). Princeton University Press. Kindle Edition. 
For what is obtained in the former is something very precious indeed: the tentacles of the state off the back of religious communities. Religious Difference, the norm Mahmood wants to protect, is thus better secured.

But if pre-modern times could not be redeemed for Foucault through historical reversal, then they will sadly have to elude Mahmood his pupil too (Mahmood's Foucaultianisms left me with a headache without making me the wiser), and in following the footsteps of her mentor in his last days, she ends her book with the oblique reference to "ethics" as our refuge from the overbearing state as a more "realistic"? alternative. She says,

This hope is symptomatic of our (not just Egyptians') collective incapacity to imagine a politics that does not treat the state as the arbiter of majority-minority relations. Given this context, the ideal of interfaith equality might require not the bracketing of religious differences but their ethical thematization as a necessary risk when the conceptual and political resources of the state have proved inadequate to the challenge this ideal sets before us.

Sadly for us, this was the concluding paragraph of the book and we are left with no guide posts as to what "ethical thematization as a necessary risk" meant though I confess it left me with the image of a Coptic pope negotiating a peace pact with a Muslim cleric over bitter coffee, on the rights and wrongs (not rights and duties) of inter communal social relations. It also left me with the queasy feeling that the ethics of the religious Patriarchs may not at all prove superior to the rights and duties of the modern liberal state, au contraire, decidedly inferior. In fact, I think, it is Mahmood's wager, and she hints at this here and there in her book, that, left to their own corporatist devices, religious patriarchs are more likely to tread the path of doing the right thing, ethically, than they would be when they are under the sleepless panoptical eye of the liberal legalist state. How this could be done is a question that is left hanging in The Minority Report, much as the thesis that female submissiveness among religiously conservative women in Egypt required relativist understanding from feminists did in The Politics of Piety, Mahmood's previous book. 


\section{Liberty as Right}

Mahmood writes,

While I appreciate the protections and freedoms that secularism might extend to religious dissenters and nonbelievers, I would also like to point out that political secularism is not merely the principle of state neutrality or the separation of church and state. It also entails the reordering and remaking of religious life and inter confessional relations in accord with specific norms, themselves foreign to the life of the religions and peoples it organizes. This dimension of political secularism-shot through as it is with paradoxes and instabilities-needs to be understood for the life worlds it creates, the forms of exclusion and violence it entails, the kinds of hierarchies it generates, and those it seeks to undermine. The two dimensions of political secularism-its regulatory impulse and its promise of freedom-are thoroughly intertwined, each necessary to the enactment of the other.

Mahmood is absolutely right that secularism reorders religious life according to norms foreign to the life of those who practice such religions. Of course it does; in fact, as a secularist myself, I should hope it does. If the opposite were true, if the principle of no separation between church and state were to prevail, then secularists like me would have had their own lives upended instead and in ways that the specific interpretation of the principle of no separation in our state would dictate. We may have to veil in public. We may have to be shepherded to mid day prayers in our work places. We may have to lie to public enforcers about not fasting in Ramadan. Many terribly unsecular things, "foreign to the lives" of us secularists would have to take place and we won't like it one bit.

\section{Better they than us, I say!}

This is all to say that the fact that secularism upends the life of the religious is nothing more than an expression of its normative victory over the counter norm- no separation between church and state- that lurks in the shadow, just about everywhere, as an alternative organizing legal principle. In so far as Mahmood claims to be thinking of secularism "critically" by pointing this particular feature of secularism then I am afraid she has instead merely reiterated the 
obvious. This is not exactly a feature of "secularism" alone, rather, any prevailing legal norm: legal norms bite and this is just the way that legal norms of secularism do!

It is when Mahmood argues that the "regulatory impulse" of secularism in fact contradicts its promise of religious liberty that I find myself pausing. To be more precise, what is baffling to me is the argument that legal regulation and liberty are opposites, that to point to the regulatory aspects of secularism is to catch secularism's claim of guaranteeing religious liberty in a gotcha moment: red handed committing an obvious contradiction.

This is so because liberty and regulation are not exactly opposites. Liberty can only express itself in regulated form and to think of regulation as a damper on liberty is to be guilty of formalist reasoning that holds little water on close inspection. In fact, and contrary to Mahmood's analysis, in which "religious liberty" is discussed independently from "minority rights" allocating a chapter for each, religious liberty is nothing but minority rights. This is so because liberty is broken down to a bundle of claims, privileges, powers, and immunities that regulate the relationship of citizens of the state on the question of religion. The total sum of these claims, privileges, powers and immunities is what we call "rights" and they are one and the same as 'religious liberty". For how a state chooses to distribute these sets of privileges, claims, powers and immunities on the question of religion is what distinguishes its own mode of secularism from the next. Each distribution affects majority/minority relations differently, a difference that is obscured if one read the signifier RL/MR formally, the way Mahmood does, and it is also a difference that may very well be worth dying for.

Take for instance the practice of "veiling" in a Muslim majority country that adopts RL/MR in its legal system. A woman might have a "right to veil" in this state as an instance of her religious liberty but this could mean different things legally. It certainly means and at minimum that she doesn't have a duty to veil. For if she does, then the privilege to wear the veil, which the "right to veil" entails is taken away from her. But a state that sees the "right to veil" as an expression of religious liberty might legally interpret this right as allowing the woman to wear the veil 
anywhere in public. But then it could do so but create an exception to the exercise of the privilege of veiling in certain places such as say "private schools" administered by Christian missionaries. Those schools are given the option of refusing to admit veiled women as students even though public schools financed by the state are prohibited from doing so. The argument being that Christian schools as are allowed to choose what violates the religious liberty of their students within the confines of their own administered schools and if they consider veiling as introducing Muslim symbolism in the public space of the Christian private school then they may very well choose to prohibit wearing it. Alternatively, a state might prohibit an exception as the above to the "right to veil", seeing in the exception a violation of the Muslim girl's religious liberty that would not be tolerated, but at the same time abstain from facilitating the right to veil. And it could do so, by prohibiting preaching the veil in the curriculum or class pedagogy of public schools. The argument being that preaching the veil violates the religious liberty of the Christian student minority. Any teacher that does so risks being expelled from his or her job. But then a state could do the opposite: it could allow for an exception to veiling in private schools but requires the assignment of state curriculum in those schools that advocates veiling as the word of God for Muslims. All of these forms of regulation are expressions of the "right to veil" itself an expression of "religious liberty" -no duty to veil-itself an expression of what Mahmood called "culture of the majority" but each has a different configuration with a different distributive consequence for the majority and the minority, or to use the rather vague and literary expression that Mahmood uses, each "creates a life form" different than the next one.

\section{Family Law}

Mahmood argues that contrary to common perception it is not "religion" that creates gender inequality, rather it is secularism, its very opposite. This is so because political secularism "jams" women, family, sexuality and religion, in the same place "the private" (as distinct from 
"public") creating a form of "cross-contamination"- the religious appropriate the family and the family acquires the quality of the religious.

In Mahmood's words:

\begin{abstract}
I argue that family law, as an autonomous juridical domain, is a modern invention that did not exist in the pre modern period. It is predicated upon the public-private divide so foundational to the secular political order, and upon a modern conception of the family as a nuclear unit responsible for the reproduction of the society and the nation. Religion, sexuality, and the family are relegated to the private sphere under this system, thereby conjoining their legal and moral fates. As a result, family law has come to bear an inordinate weight in the reproduction and preservation of religious identity.
\end{abstract}

Note here how, in order to register her next critique of "political secularism", Mahmood drops in the paragraph above all reference to the liberal legal complex of "liberty/rights" that characterized her previous discussion and transitions to another one, namely, "the public/private" one. This might be because the rule that addresses all Egyptians, religious majority and minority: "You are under the duty to marry according to the doctrine of the religion you are born into" is an expression neither of "religious liberty" nor indeed of "minority rights". It is not exactly a grand expression of "secularism". Whatever invisible line there is that separates "secularism", with all the internal possibilities of its articulation, is crossed here to something that is "not-secularism".

If, however, the Egyptian state kept the rule above, namely, "the duty to marry according to religious law", but also allowed for an opt-out right of marrying according to "civil law" and made this right available to all Egyptians, then we would still be within the domain of the "religious liberty" of secularism. But then if such an option existed, many Egyptians, Muslims and otherwise, would have flocked to this opt-out, thereby "minimizing" religious difference. It would then be hard to argue, as Mahmood does, that it was "secularism" that exaggerated religious "difference" (or gender inequality); and the more common one that it was unfinished secularism that was the culprit would make much more sense. 
Moreover, it would be preposterous to argue that a state that regulates marriage according to civil law, but that also allows people to marry according to their own religious ceremonies, such as the US, sits on the same "political secularism" spectrum with a state such as Egypt that requires people to marry according to their respective religious laws just because both laws, civil and religious, are passed by the state. They may sit on the same "patriarchal" spectrum, depending on the particular family rules passed in each; they may sit on the same public/private divide spectrum with the family treated as the domain of the "private" in both, but they can't possibly be described as sitting on the same "secularism" spectrum. To expand the meaning of "secularism" to everything the modern state passes as law that takes religion as its object- whether it permits its public expression, or requires it or prohibits it- is to make "secularism" literally incoherent by eroding the difference between it and its opposite. It is in effect to argue that living in a state that orders women to veil in public such as Saudi Arabia and Iran is same as living as a woman in a state such as the US that does not.

To do so risks sounding absurd.

\title{
EIPR (Egyptian Initiative for Personal Rights)
}

\begin{abstract}
As I mentioned, I could not have written Religious Difference in a Secular Age without conducting work with EIPR and other minority-rights groups in Cairo. However, as I worked with these activists, I realized that the assumptions that informed their work were not simply "theirs" but belonged to a global political discourse that exerts an immense force on our collective imagination..... Upon my return from Egypt, as I began the process of analysis and writing, I was compelled to dig beyond the ethnographic encounter to grasp fragments of the past congealed into the present....this process in turn required an engagement with historical materials from $18^{\text {th }}$ century to the present...The book thus could not have been born without the ethnographic encounter, but also had to transcend it in order to make sense of what I encountered.
\end{abstract}

This has become somewhat of a familiar trope ${ }^{2}$ : the anti-enlightenment US-based academic "transcends the ethnographic encounter" with the local activist who had gone out of his/her way to host and assist the visiting anthropologizing academic, by discovering, upon going back

\footnotetext{
${ }^{2}$ It is so familiar I am starting to think it is necessary. I have commented on it twice: See https://www.opendemocracy.net/5050/lama-abu-odeh/holier-than-thou-antiimperialist-versus-local-activist and
}

http://english.al-akhbar.com/node/15350 
home to America, to where the land of enlightenment is you might say, that the local activist was in the grip of an enlightenment discourse that was globalized (bummer!) but that had the problem that it limited "our collective imagination"! The sense of admiration the academic may have had for the work of the activist when they were in the very local place, and Mahmood is full of praise for the work of the lawyers of EIPR, becomes a tad ambivalent from a distance as the activist now appears to be suffering some kind of a "false consciousness", you know, the type you have when you're into too much enlightenment!

As I know some of the lawyers who work at EIPR and as I am familiar with the work they do, I find it hard to believe that those lawyers were not aware that "the assumptions that informed their work were not simply theirs!" They knew all right that they were part of a globalized rights movement and that they were deploying the international language of human rights: religious liberty, minority rights and all! I suspect though that these lawyers' secularism, which they had put into good activist use on behalf of the Copts and other religious minorities through careful deployment of rights discourse, didn't go down well with Mahmood whose academic agenda, as this book quite amply represents, is antagonistic to secularism.

And even though "the assumptions that informed [these lawyers'] work... belonged to a global political discourse", contrary to Mahmood, I think these assumptions were very much "theirs". For Mahmood makes much of the tainted origins and the bad company that "political secularism" had historically kept in its long and illustrious traveling career across the oceans. From its early origins as a ruse to allow European powers to intervene in the affairs of the Ottoman Empire on behalf of religious minorities, to its later association with bad projects such as neoliberalism, American Evangelism, and Copts of the US diaspora, "religious liberty" knocked on the door of the "orient" threateningly in the context of "differential sovereignty". As the recipients of secularism gave no proper "consent", and even worse, something precious was lost in the process, namely, "religious difference", this secularism became irredeemably tainted for Mahmood. Its globalism was imperialism simpliciter, or so seemed the suggestion of The Minority Report. 
And yet what the EIPR lawyers did so well and so effectively was to see in this secularism its universalist promise and by putting it to good activist use made it very much their own. For "RL/MR" the defining principles of secularism is nothing but a compromise formation on the twin universal norms of equality (of citizenship) and liberty (of religious practice), the details of which, how it would be translated into laws and regulations, was an object of struggle for rights that these lawyers chose to wage and push to define. As I tried to show in my discussion of the possible rules that this configuration could produce, the difference between the one and the other may very well be a difference worth dying for! Rather than "limit the imagination", it was the very stuff that fired it up!

Far from seeing the inevitable complexity of the compromise formation equality/liberty of secularism as these lawyers did, Mahmood treated any incursion from the former (equality) on the latter (liberty) paranoia-cly, as only a radical libertarian would do. Any form of regulation of religious liberty, or what she likes to call "religious difference", for the purposes of promoting equality was excoriated as too intrusive and used to show the "contradiction and paradox of secularism".

In short, while EIPR lawyers struggled for Egyptians to be equal and free in the only state they knew and lived in, Mahmood waxed libertarian (denouncing regulation), anarchist (denouncing the state) and religious conservative (nostalgic for the Ottoman) all at the same time!

She may win the contest on "imagination", but the one on "justice", I am afraid the EIPR lawyers will have to win each time. 


\title{
Conclusion
}

Reading The Minority Report was a very odd experience. A book on secularism in Egypt that doesn't make a single reference to Al Sahwa Al Islamiyya ("The Islamic Awakening") the social phenomenon that has haunted the lives of Copts (as well as Muslims), for decades now, and pushed them to either migrate to the West in waves in fear for their lives and livelihood or to alternatively seek protection by supporting dictatorships, leaves the reader thinking that they had just finished reading not a tract on theory exactly, but on ideology, and not the good kind!

It seems odd not to engage with a phenomenon the Egyptian historian Sherif Younis, describes in this manner:

\begin{abstract}
[Al Sahwa] has colored the lives of people across the span of forty years with the darkest of tones: popularizing accusatory and violent language as well as the sense of grievance and siege in popular and semi official religious discourse; giving rise to the violence of explosions and suicides that has killed people and upended their lives, their livelihood and their sense of security; touching the lives of the non Christian Arabs, instilling dread and fear in their hearts, threatening them in their possessions and nurturing sectarian feelings among the populace; it has undermined the status of women in society, threatened public rights and liberties, created a regime of censoring terror among writers and artists, and left a trail of death material and psychological in its trail.... All of this under the heading "The Return to Islam" whose grand theorist was Sayyed Qutub. ${ }^{3}$
\end{abstract}

It is this that EIPR lawyers were intervening in on behalf of Al Sahwa's victims. Of course, there are many interesting theoretical questions that could be posed about this secularism, including the role of the modern Egyptian state in delimiting its compromised form and the ways in which it is complicit in this Sahwa, but those would have only been possible if sufficient account of what that secularism was intervening in was offered by Mahmood. Instead what was produced was something of a mystification in which "secularism" itself was made to appear as if it were the culprit behind Coptic misery.

\footnotetext{
${ }^{3}$ Talk delivered at a conference in Morocco in 2014 entitled, "Impediments to the Renewal of Islamic Discourse and its Dynamics: Islam as a Locus of Conflict". Manuscript with author.
} 
The Minority Report is a text that tries to respond to the problem of essentializing Islam (the culturalism problem) by performing a flip so that all the bad attributes typically associated with "Islam" are now attributed to secularism instead. It is secularism that discriminates, that is sectarian, that encourages violence, that is repressive, sexist, etc. This Mahmood does by on the one hand hyper-politicizing secularism (depleting it of its universalist drive), and on the other under-politicizing it by ignoring its internal indeterminacy, complexity, open structure and varied distributive effects. The result is an account that moves between crude historicismsecularism is its history- and formalist generalizations reminiscent of the ways "Islam" is treated in mainstream discourse. Islam is nothing but the history of its conquests and its doctrines create the world in a specific way.

But a flip does not a critique make. 